\title{
The effect of summer pruning on solar radiation conditions in apple orchards
}

\author{
Gonda I., Lakatos L., Rakonczás N. \& Holb I. \\ University of Debrecen Centre of Agricultural Sciences Faculty of Agriculture \\ Department of Horticulture and Plant Biotechnology
}

\begin{abstract}
Summary: The aim of this study was to measure the solar radiation conditions in the tree and around the tree of pruned (summer pruning) and unpruned trees in an intensive apple orchard. When observing the daily trend of global radiation measured, there was a great reduction at midday hours due to the shadowing effect of the canopy. The reduction reached $70-75 \%$ before pruning, while after pruning it was only $20-25 \%$. The relative radiation supply of the canopy space on cloudy days in the morning and late afternoon hours was higher than that of the sunny days. Mean differences between the day and night temperature reduced greatly in the period of intensive fruit colouration in August and September both in the plant stock and outside the plant stock.
\end{abstract}

Key words: summer pruning, apple, solar radiation.

\section{Introduction}

Quality apple production requires excellent fruit colouration in addition to proper fruit size. In spite of the best winter pruning, it is obvious that the newly grown plant parts shadow smaller or larger portions of the fruit even in the case of the small-sized trees of intensive orchards, thereby, the chances of colouration are harmed. In such cases, summer pruning provides a good option for reducing the number of shadowing plant parts and for targeting good colouration of $100 \%$ of the fruits on trees with average or below average fruit load.

Solar radiation conditions in the plant stock have been studied mainly via their indirect effects so far. Intensive solar radiation accompanied by high temperatre might cause quality deterioration in the case of pome fruits. One of its most characteristic processes is the sunburn of fruits (Gonda, 1999). The surface injury caused by intensive solar radiation results in a slight russetting and colouration in the first phase, and then epidermal injury appears on the fruit surface exposed to radiation. Sunscald is a physiological injury of the fruit, which greatly influences the fruit's quality and reduces its product value. The deformation appears primarily in the surface and subsurface layers of the fruit. Later, phytopathogenic fungi (e.g. Alternaria tenuis, Physalospora obstusa, Monilia fruticola, Monilia laxa, Monilia fructigena, Glomerella cingulata, Venturia inaequalis) may infect the apple fruit via the injured epidermis (Holb, 2003).

Fruit crops respond quite sensitively to quick and significant changes in their environment. The number and activity_of stomata play an important role in the regulation of heat and water balance of plants. At a smaller number of stomata, water release is reduced, therefore, the plants and fruits may strongly warm up during the day hours.
Symptoms appear mainly in those areas, where i) Air temperature is high, relative humidity is low and the number of sunny hours is high in the ripening period. ii) Furthermore, the damage is also high, if cold or mild weather is followed by a hot period with burning sunshine after a short transition. iii) If the change does not come suddenly, then the plant can adapt to the altered climatic conditions, therefore, the risk of sunburn reduces. iv) Damage is especially intensive, if water stress also occurs during this period.

Growing regions of western Transdanubia and Tiszántúl receive different amounts of sunny hours in the different months. During the period from November until March, the Zala region receives the highest amount of solar radiation, while in the growing season, the sunny period is 10-20 hours longer per month in the fruit orchards of Hajdúság. Except for January and June, the variability of the sunny period is larger in the western Transdanubian areas. This is due to circulation reasons, since the Zala region is reached more frequently by Atlantic and mediterranean cyclones.

In addition to solar radiation, the following factors also have a role in the formation of sunscald symptoms: i) radiation energy absorption capacity, ii) specific photostability, iii) tolerance toward temperature and UV radiation, and iv) adaptability and sensitivity to environmental factors.

Gonda $(1995,2000)$ claims that the causes of sunscald are very high temperatures accompanied by extremely low humidity and the resulting water deficiency. As further predisposing factors, he lists nutrient metabolism disorders and the weak condition of trees. According to his experience, the previously shadowed fruits that come to light after summer pruning almost never show symptoms of sunburn. Of course, this might also be due to the fact, that after performing summer pruning classically in August, the burning high temperatures and low relative humidities are 
more scarce. Sunburn is obseved mainly in July in Hungary. The degree of damage is not yet high in June and becomes lower in August.

Intensive solar radiation increases the day temperatures. The degree of colour cover is determined mostly by the difference between day and night temperature (Lakatos et al., 2005). The average night temperature of the vegetation period has increased greatly for the last 20 years. Increase in temperature is significant at $0.1 \%$ probability level. Higher night temperature usually has an unfavourable effect on production. Respiration becomes more intensive, therefore, the daily weight gain becomes smaller. Numerous quality indicators, e.g. sugar content, are lower at higher night temperatures, since the energy needed for the increased respiration intensity is covered from the reserves of the plant. An increase can also be observed in day temperatures, however, it is smaller than that of night temperatures. The average difference between day and night temperatures during the vegetation period has decreased for the past 20 years (Lakatos et al., 2005). The reduction confirms, that the increase in night temperatures is greater than the change int he day temperature. Accordingly, if this trend continues, then a further quality deterioration should be expected in the future.

Research on plant stock climate has been started in the $1950 \mathrm{~s}$ in Hungary. The peculiarities and physical characteristics of plant stock climate became widely known via the works of the university researchers of Debrecen (Berényi, 1952, 1953; Justyák, 1957, 1960; Szász, 1956) Int he 1960s, numerous studies were performed to analyze the macro- and microclimatic effects on fruit growth in the stock climate of grape and fruit orchards by Szász (1961), and to evaluate the role of agrometeorology in domestic fruit production by Nyujto (1965). The studies published at the end of the sixties studied mainly apple and grape cultures (Csöbönyei \& Stollár, 1969). These results were efficient in improving the yield safety of fruits and in enlarging our knowledge on cultivar performance. In the 1970s, numerous results were obtained on the relationship between fruit growth, soluble solids content and weather. In the 1980s, more attention was paid to the meteorological background of cultivar-specific site selection (Stollár \& Zárbok, 1981), to the study of heat and radiation supply of plant stock (Dunkel et. al., 1981) and the effect of critical winter temperatures on the overwintering of fruits (primarily in grape cultures) (Dunkel \& Kozma, 1981; Csapó, 1984).

$\mathrm{Via}$ the research results, an information base was created which enabled a significant development in stock climate research.

In the 1990s, the temporal dynamics of heat deficiency and surplus in plant stock was the major focus of stock climate research (Kocsis \& Ligetvári, 1992). However, most of the stock climate studies in Hungary were limited to field crops (Anda, 1993, Hunkár \& Bacsi, 1993). Results on fruit stock climate were published by Tökei et al. (1995), Tökei \& Szász (1997), Lakatos (2002) and Tökei \& Dunkel (2004) in recent years.
The aim of our study was to measure the solar radiation conditions in the tree and around the tree of pruned (summer pruning) and unpruned trees in an intensive apple orchard.

\section{Materials and methods}

The study was carried out at the intensive apple orchard of Kasz-Coop Co. (Derecske) planted in 1998 on M9 rootstock. The distance between rows and within rows was $4 \mathrm{~m} \times 1 \mathrm{~m}$ ( 2500 trees/ha) in the orchard with slender spindle crown form.

The meteorological recording system is of Hungarian development with 24 channels and SM2 data logger equipped with high-sensitivity and high-precision (thermohygrograph) sensors at three heights $(50 \mathrm{~cm}, 120 \mathrm{~cm}, 250 \mathrm{~cm})$. Wind speed and wind direction data are measured directly above the plant stock at $250 \mathrm{~cm}$ height. Int he canopy layer, radiation recorders are placed which measure global radiation and radiation balance. In the layer of trunks, a pluviometer is placed. In this way, the reduction in radiation in the plant stock and the degree of interception can be calculated.

In this study, the results of the period between 1 April 2005 and 31 October 2005 are presented. The average daily trends were constructed from the hourly recorded data of the vegetation period. We studied the effect of different tree heights, trunk thickness parameters and densities resulting from the age of the orchard on the temperature, humidity and radiation conditions of the plant stock in apple orchards of different age. In all the three studied orchards, the meteorological recorders were placed among cv. Golden Reinders trees. In order to avoid the edge effect, the recording stations were placed at $25-30 \mathrm{~cm}$ from the beginning of the row.

\section{Results}

\section{Radiation supply conditions in the orchard}

When observing the daily trend of global radiation measured, it can be seen that there is a great reduction at midday hours due to the shadowing effect of the canopy. The reduction reaches $70-75 \%$ before pruning, while after pruning it is only $20-25 \%$ (Figure I).

Due to the N-S direction of rows, the shadowing effect of leaves is the greatest in the midday hours, but a significant reduction in radiation can be expected also in the late afternoon hours.

When studying the radiation supply of the canopy layer, the daily radiation trend of sunny and cloudy days is also an important question.

Among the 15 days before the pruning, there were 3 almost totally cloudy and 3 cloudless days. The global radiation ratios recorded on these days are presented in Figure 2.

The results indicate that the relative radiation supply of the canopy space on cloudy days in the morning and late afternoon hours is higher than that of the sunny days. Figure 2 also illustrates that the daily amplitude of the relative 


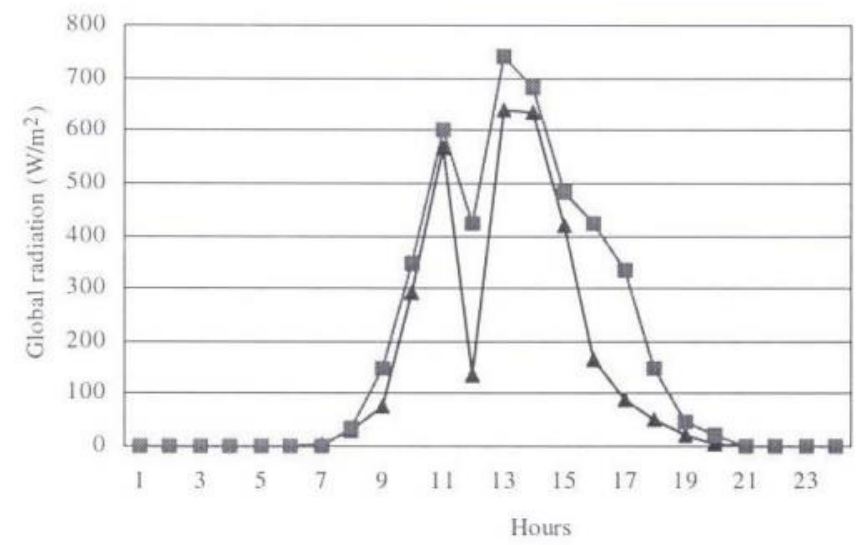

Figure 1. The daily trend of global radiation in the canopy layer before (blue line with triangle) and after summer pruning (red line with square) (Derecske, 2005)

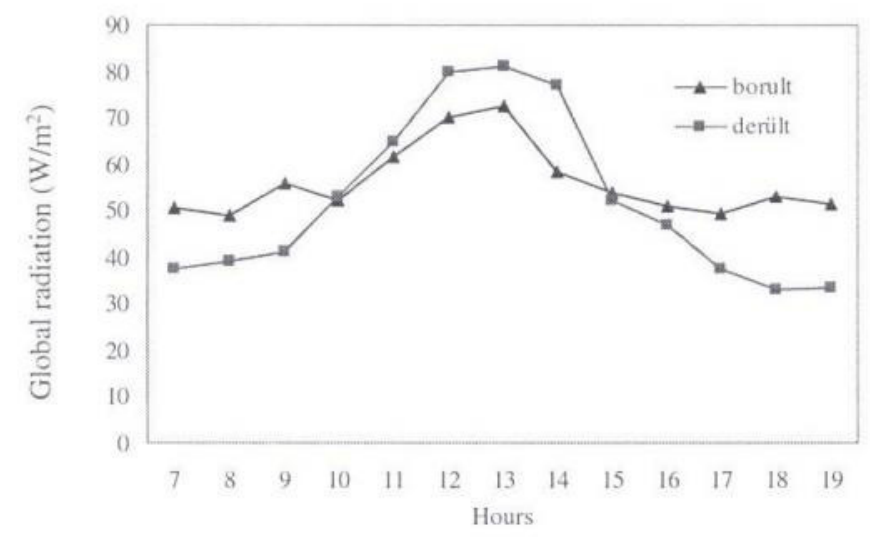

Figure 2. The global radiation ratio of the canopy space in the period before pruning on cloudy (blue line with triangle) and sunny days (red line with square) as compared to radiation of the space outside of the plant stock (Derecske, 2005)

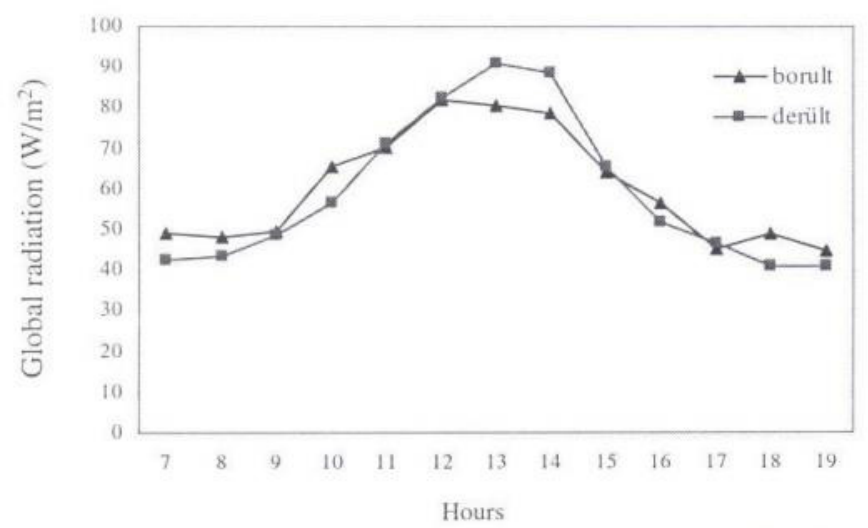

Figure 3. The global radiation ratio of the canopy space in the period after pruning on cloudy (blue line with triangle) and sunny days (red line with square) as compared to radiation of the space outside of the plant stock (Derecske, 2005)

radiation supply of sunny days is almost $50 \%$, while on cloudy days the difference between maximum and minimum values is not higher than $20 \%$.

We selected 3 cloudless and 3 cloudy days also from the 15-day period after pruning. The global radiation trends of these days are included in Figure 3.

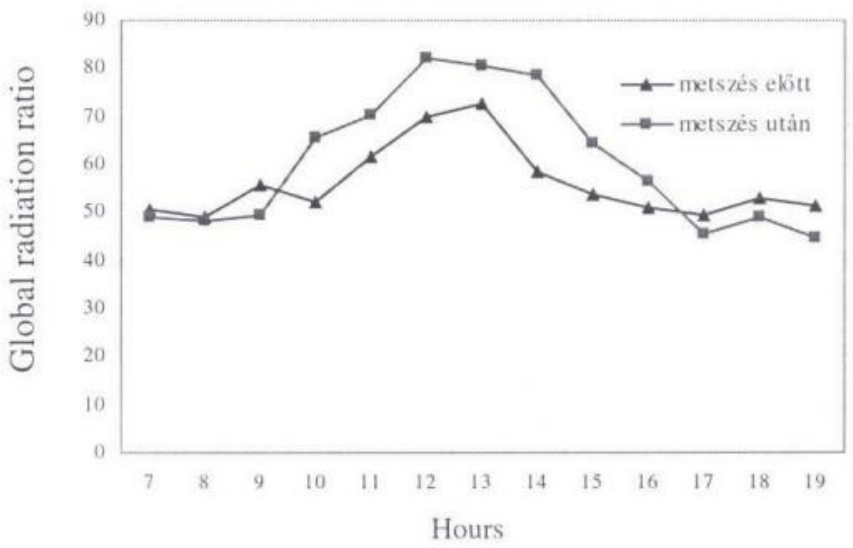

Figure 4. The global radiation ratio of the canopy space in the period before (blue line with triangle) and after summer pruning (red line with square) on cloudy days as compared to radiation of the space outside of the plant stock (Derecske, 2005)

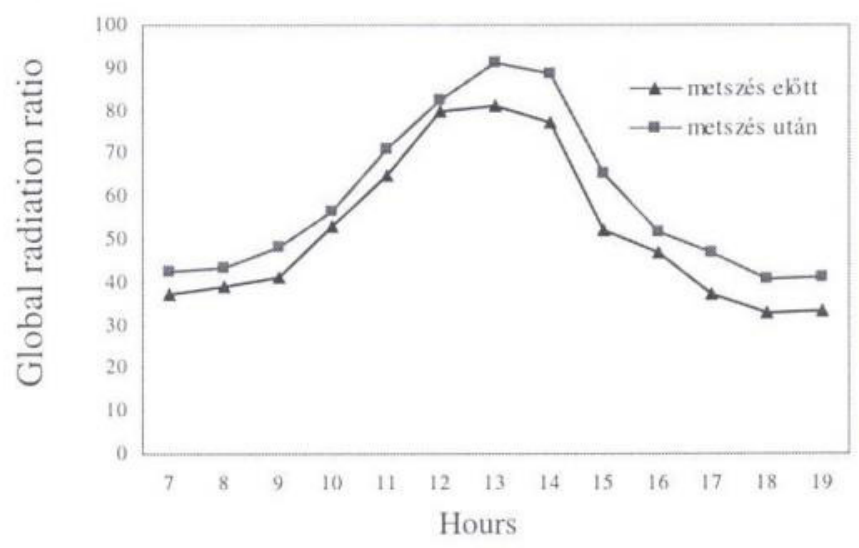

Figure 5. The global radiation ratio of the canopy space in the period period before (blue line with triangle) and after summer pruning (red line with square) on sunny days as compared to radiation of the space outside of the plant stock (Derecske, 2005)

Pruning increases the relative radiation supply of the canopy space by about $10 \%$. The largest differences in the relative radiation supply trend of sunny and cloudy days can be observed in the midday and early afternoon hours. In the morning and in the afternoon, the radiation supply of sunny and cloudy days is almost the same, while in the morning and in the late afternoon hours the relative radiation supply of cloudy days is higher than that of sunny days.

If we analyse the relative radiation supply trends separately for sunny and cloudy days, then we can evaluate the effect of pruning. Based on our results, it can be stated that the relative radiation supply of cloudy days in the morning and afternoon hours is $8-10 \%$ higher than that of sunny days (Figure 4).

Results indicate that the relative radiation supply from the morning hours until the afternoon hours on cloudy days in the period after pruning are about $10 \%$ higher than the values before pruning. In the early morning and late afternoon hours, the radiation supply in the period before pruning can be higher than that of the period after pruning. 
The relative radiation supply of sunny days in the midday hours in the perod after pruning is $8-10 \%$ higher than that of the period before pruning (Figure 5).

Based on the results, it can be stated that the relative radiation supply on sunny days in the period after pruning is $4-10 \%$ higher during the whole day than that in the period before pruning. The largest differences can be observed in the early and late afternoon hours.

\section{Changes in the difference between night and day temperatures in the plant stock}

Figure 6 shows the average difference between day and night temperature in the different months in the plant stock and outside the plant stock.

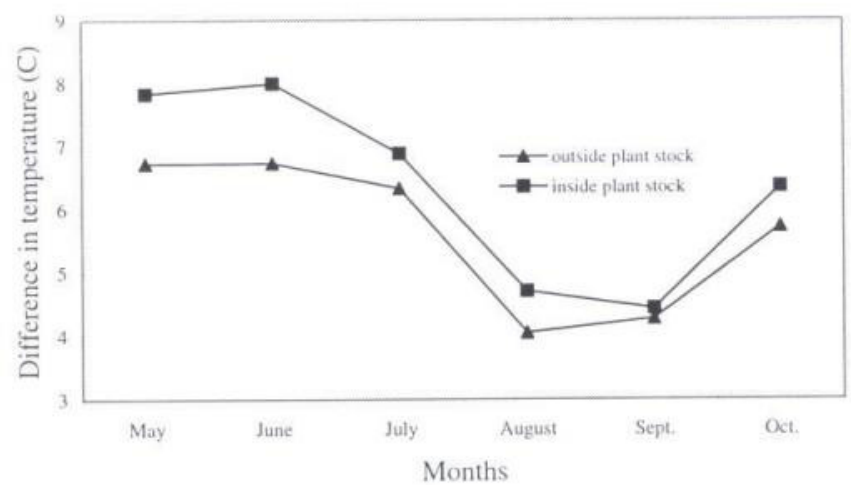

Figure 6. Changes in the difference between average day and night temperature in the different months in the plant stock and outside the plant stock (Derecske, 2005)

It is obvious from the figure that the average difference between the day and night temperature reduced greatly in the period of intensive fruit colouration in August and September both in the plant stock and outside the plant stock.

Figure 7 demonstrates that the difference between day and night temperature reduces as a result of summer pruning.

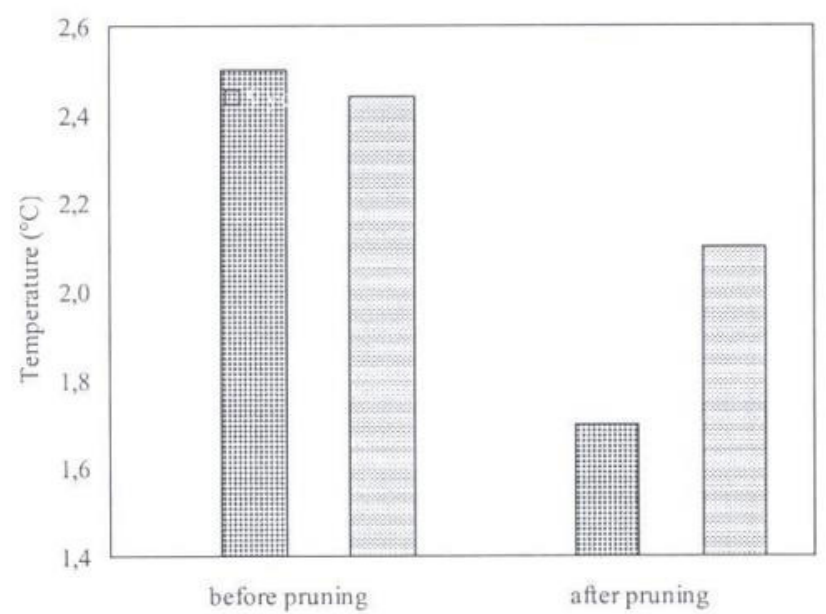

Figure 7. Average difference between day and night temperature before and after pruning (Derecske, 2005)

\section{Discussion}

Figure 8 shows the recorded values at all ages, taking into consideration that summer pruning was only started in the 7year-old orchard. All the measurement tools were placed in the block of cv. Golden Reinders (not colouring), which normally would not receive summer pruning, since the increased radiation colours this cultivar to a certain level, which causes problems in sales in Hungary.

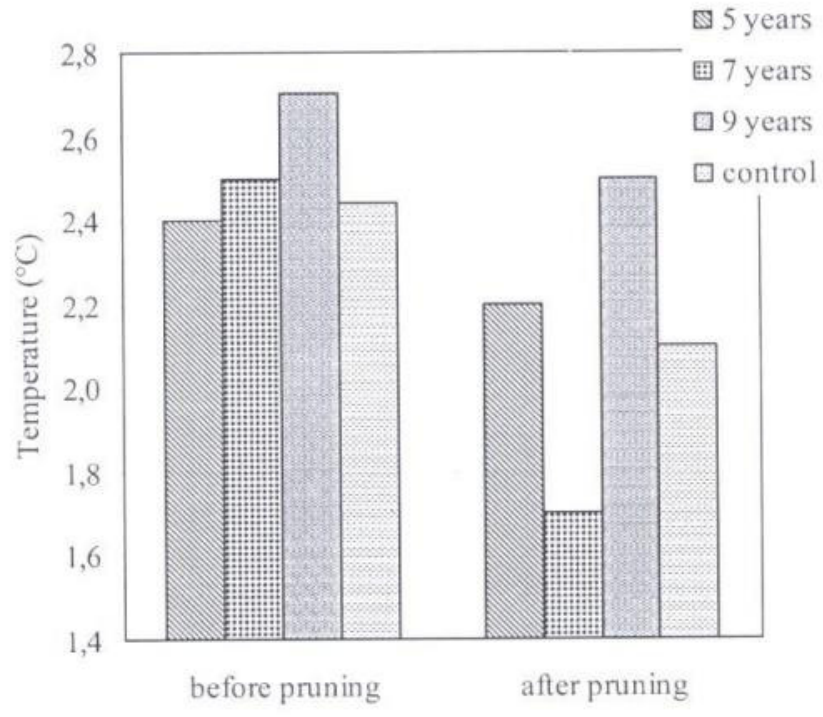

Figure 8 . The average difference between day and night temperature in plant stocks of different age before pruning and after pruning (Derecske, 2005)

On the one hand, the order of different ages in the respect of the difference between day and night temperature can be seen before pruning: the fluctuation of temperature is higher in older orchards.

On the other hand, the Figure also demonstrates clearly, that the difference between day and night temperature greatly reduced in the 7 -year-old orchard with summer pruning.

Figure 9 represents the \% change in the difference between day and night temperature in the period after pruning as compared to values before pruning.

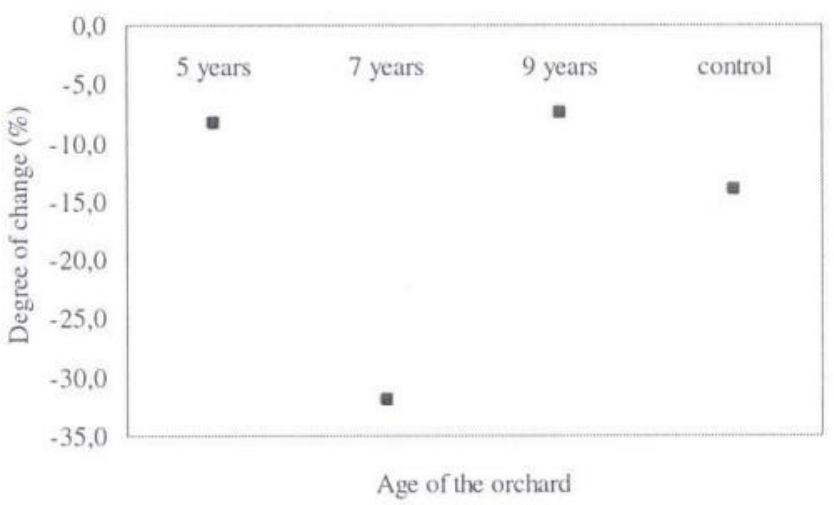

Figure 9. Percentage changes in the difference between day and night temperature in the period after pruning as compared to the values before pruning (Derecske, 2005) 
By studying the plant stock climate and within this the radiation conditions, we have a chance to act against the unfavourable weather effects (to a certain extent). We can successfully reduce the damage caused by late spring and early autumn frost, the length of heat and water stress, the risk of sunscald, if we know the physical characteristics of the space inside the plant stock.

\section{Acknowledgements}

The equipment for climatic measurements was purchased from the OTKA grant no. M 041490. For setting up the research program of the present study, for operating the surveillance system and for performing the experiments, the financial sources of the OTKA grant no. T/038327 were used.

\section{References}

Anda, A. (1993): Surface temperature as an important parameter of plant stands. Idöjárás. 97: 259-267.

Berényi, D. (1952): A különbözö sürüségü öszi rozsvetések állományéghajlata. Debreceni $\mathrm{Mg}$. Kisérleti Int. Évkönyve. 107-140.

Berényi, D. (1953): A vetéssorok égtáji irányitásának hatása a mezögazdasảgi növények állományklimájảra. MTA Müszaki Tud. Oszt. Közl. X. 3-4: 651-666.

Csapó, P. (1984): Szölöültetvények téli fagykárának becslése. Légkör. 1984. 19-21.

Dunkel, Z. \& Kozma, F. (1981): A szölö téli kritikus hömérsékleti értékeinek területi eloszlása és gyakorisága Magyarországon. Légkör. 2: 13-15.

Dunkel, Z., Kozma, F. \& Major, Gy. (1981): Szölöültetvényeink hömérséklet- és sugárzás-ellátottsága a vegetációs idöszakban. Idöjảrás. 4: 226-234.

Gonda, I. (1995): Az intenziv almatermesztés hazai tapasztalatai és perspektivải. Új Kertgazdaság. 1: (3) 62-64.

Gonda, I. (1999): Az alma nyári metszésének hatásai. Kertgazdaság. 31: 132-133.
Gonda, I. (2000): Minöségi almatermesztés. Primon Vállalkozásélénkitö Alapitvány Vállalkozási Központ. Nyiregyháza.

Holb, I. (2003): The brown rot fungi of fruit crops (Monilinia spp.) I. Important features of their biology (Review). International Journal of Horticultural Science. 9 (3-4): 23-36.

Hunkár, M. \& Bacsi, Zs. (1993): Kisérletek talaj-növény-idöjárás modellekkel. Meteorológia és növénytermesztés. 59-65.

Justyák, J. (1957): A paradicsom állományklima vizsgálatának 5 éves eredményei. KLTE Met. Int. Tud. Közl.3: 42.

Justyák, J. (1960): A müvelési módok hatása a szőlö állományklimájára Tokaj-Hegyalján. Kandidátusi értekezés. 300

Kocsis, L. \& Ligetvári, F. (1992) Elökészületek a Scheduler növényi stresszmérö készülèk adaptációjảra. Magyar Szölö- és Borgazdaság II. 1: 5-81.

Lakatos, L. (2002): Ảllományklima vizsgálatok almaültetvényben. Innováció, a tudomány és a gyakorlat egysége az ezredforduló agráriumában. Kertészet. Debrecen. ISBN 9639274291. 12-22p.

Lakatos, L., Szabó, T., Racskó, J., Szabó, Z., Soltész, M. \& Nyéki, J (2005): A nappali és éjszakai hömérséklet hatása a gyümölcsök fedöszinének alakulására alma génbank ültetvényekben. Agrárátudományi Közlemények Acta Agraria Debreciensis. 2005/17: 45-53 p.

Nyujtó, F. (1965): Gyümölcstermesztés és agrometeorológia az Alföldön. Kertészet és szölészet. 15: 8-9.

Stollár, A. \& Zárbok, Zs. (1981): A gyümölcsök optimális termöhelyének elemzése hömérsékleti adottságok alapján. Légkör. 3. $15-17$.

Szász, G. (1956): A talajkülönbségek hatása az öszi árpa állományéghajlatára. Agrokémia és Talajtan. 5: 471-484.

Szász, G. (1961): Makro és mikroklimatikus hatások a köszméte bogyók növekedésére és beltartalmára. Idöjárás. 1961. 5: 79-288.

Tökei, L. \& Szász, G. (1997): Gyümölcsültetvények állományklimája. In: Meteorológia mezögazdáknak, kertészeknek, erdészeknek. Mezögazda Kiadó. Bp. 526-543.

Tökei, L., Gránási, T., Ligetvári, F. \& Bulátkó, F. (1995): A növényi felszinhömérséklet vizsgálata almaültetvényben. Új Kertgazdaság. 3: 18-24 p.

Tökei, L., Dunkel, Z. (2004): Investigation of crop canopy temperature in apple orchards. Physics and chemistry of the Earth. 2004. Published by Elsevier Ltd. 